\title{
Internal Parasitism of Steers Grazing Extensively at Different Stocking Rates
}

\author{
By S. M. Thamsborg ${ }^{1,2}$, R. J. Jørgensen ${ }^{1}$ and P. Nansen ${ }^{2}$
}

${ }^{1}$ Department of Clinical Studies, Large Animal Medicine, ${ }^{2}$ Danish Centre of Experimental Parasitology, The Royal Veterinary and Agricultural University, Frederiksberg, Denmark.

\begin{abstract}
Thamsborg SM, Jørgensen RJ, Nansen P: Internal parasitism of steers grazing extensively at different stocking rates. Acta vet. scand. 1998, 39, 311-323. - Eightyfour first-year grazing Holstein-Friesian steers were observed through 2 years on 40 ha of reclaimed unfertilized grassland with the objective of investigating the influence of stocking rate (SR) on internal parasitism under extensive grazing conditions. Three groups of steers were grazed each year at low, medium and high SR in separate paddocks $(0.53,1.05$ and 1.55 steers/ha). The faecal egg counts of predominantly Cooperia and Ostertagia spp. were influenced by SR in the first year $(p<0.05)$ with maximum geometric means of 135,182 and 217 epg in the low, medium and high SR groups, respectively, and part of the second year $(p=0.08)$ with maximum geometric means of 88,134 and 195 epg. In the second year, all steers were treated with levamisole by 26 July due to diarrhoea, being particularly severe at high SR and 7 steers were withdrawn from this group at the same time. Serum pepsinogen levels indicated a higher rate of uptake of $O s$ tertagia larvae in higher SR groups in the second season before treatment $(\mathrm{p}<0.01)$. The mean weight gains ( \pm s.d.) for the first year were $630 \pm 58,341 \pm 97$ and $300 \pm 151 \mathrm{~g} /$ day in the low, medium and high SR groups, respectively, and in the second year the corresponding figures were $565 \pm 109,357 \pm 135$ and $247 \pm 129 \mathrm{~g} /$ day. Although the SRs were much lower than commonly found on improved pastures, we conclude that feed on offer was a limiting factor in late season and secondly, that the levels of exposure and uptake of nematodes in steers were affected by SR. The levels of parasitism at the medium and high SR were high enough to have affected production.
\end{abstract}

cattle; grassland; nematodes; beef; production; management.

\section{Introduction}

Extensive grazing, such as on range land, is becoming increasingly common in Denmark in protected public areas and where farm land is taken out of crop rotation due to marginal profitability, public subsidies or other reasons. Grazing with livestock is introduced, or reintroduced, in order to conserve or create a socalled "open landscape". The production of herbage per ha is often low and of poor quality, and since such areas may be subject to certain environmental regulations, the use of fertilizers and pesticides may be restricted or banned. These factors, together with the lack of possibility of harvesting a portion of the pasture for silage or hay during flush growth periods, make a contrast to intensive grazing systems. In many instances, animals grazing such areas may suffer periods of low feed availability, trace mineral deficiencies, and in addition pastures or parts of pastures free of parasites are not available. Adjusting stocking rate (SR) by altering the number of animals per unit area over a pe- 
Table 1. Mean temperature and rainfall during year 1 and year 2 of study of parasitism of steers at different stocking rates.

\begin{tabular}{lcccccccc}
\hline & \multicolumn{9}{c}{ Month } \\
\cline { 2 - 8 } & Apr & May & Jun & Jul & Aug & Sep & Oct & Nov \\
\hline Mean temperature $\left({ }^{\circ} \mathrm{C}\right):$ & & & & & & & \\
Year 1 & 7.3 & $\mathbf{1 3 . 8}$ & 14.7 & $\mathbf{1 5 . 1}$ & $\mathbf{1 4 . 6}$ & $\mathbf{1 1 . 2}$ & 7.4 & 2.6 \\
Year 2 & 7.4 & 10.7 & 13.6 & $\mathbf{2 0 . 3}$ & 17.8 & 13.1 & 7.8 & 6.2 \\
Long term average $^{1}$ & 6.1 & 11.0 & 15.0 & 17.2 & 16.9 & 13.8 & 9.3 & 5.5 \\
& & & & & & & & \\
\hline
\end{tabular}

\begin{tabular}{|c|c|c|c|c|c|c|c|c|}
\hline \multicolumn{9}{|l|}{ Precipitation $(\mathrm{mm})$ : } \\
\hline Year 1 & 12.6 & 6.4 & 47.2 & 103.6 & 72.7 & 125.2 & 40.8 & 30.7 \\
\hline Year 2 & 49.6 & 30.8 & 44.1 & 7.0 & 49.5 & 139.2 & 35.3 & 58.1 \\
\hline Long term average & 35 & 40 & 45 & 57 & 55 & 53 & 47 & 32 \\
\hline \multicolumn{9}{|l|}{ Waterbalance $(\mathrm{mm})$ : } \\
\hline Year 1 & -51 & -79 & -68 & 10 & -7 & 103 & 47 & n.d. ${ }^{3}$ \\
\hline Year 2 & -21 & -51 & -51 & -126 & -22 & 103 & 11 & n.d. \\
\hline Long term average & -8 & -34 & -35 & -42 & -36 & 1 & 29 & n.d. \\
\hline
\end{tabular}

Meteorological data from Copenhagen Airport, 1993-94. Courtesy of Danish Meteorological Institute.

1 1960-1990.

2 boldfaced figures refer to text in materials and methods.

${ }^{3}$ n.d. $=$ not determined.

riod of time and/or provision of bought-in supplementary feed may thus be key factors in the management. SR is in general, considered the most important factor affecting the efficiency of pasture utilization as increasing SRs up to a certain limit, will increase the output in terms of animal production per hectare despite lowering the production per head.

In studies confined to intensive cattle grazing systems, SR has been shown to affect the uptake of nematode parasite infections (Hansen et al. 1981; Nansen et al. 1988). We designed the present 2-year study to assess the influence of SR on nematode infection levels in first-year grazers under extensive grazing conditions characterized by low SRs (less than 2 ani$\mathrm{mals} / \mathrm{ha}$ ). On improved pastures stocking rates of 6-10 animals/ha are not uncommon. In this investigation, we used steers of dairy breeds. Grazing steers may present an alternative to the traditional indoor fattening of bull calves in Denmark. This alternative has not been evaluated in detail neither with regard to productivity nor to parasitism or other loss-producing factors.

\section{Materials and methods}

\section{Study area}

The area was part of a grassland nature reserve located on the island of Amager near Copenhagen. Forty hectares of reclaimed land of high salinity (1.0-1.5 m below sea level) grazed by steers for 2 years were divided into 3 paddocks of similar size. The area was covered by natural vegetation and some places were waterlogged in spring and autumn. Animals were watered by mechanical pumps drawing water from drainage ditches. The predominant herbage included red fescue (Festuca rubra), mud rush (Juncus gerardii), creeping bent (Agrostis stolonifera), 
Table 2. Mean ( \pm s.d.) daily weight gains prior to supplementation and the production per hectare, adjusted to 129 days of grazing.

\begin{tabular}{|c|c|c|c|c|c|c|}
\hline & \multicolumn{5}{|c|}{ Stocking rate } & \multirow[b]{2}{*}{ High } \\
\hline & $\mathrm{n}^{1}$ & Low & $\mathrm{n}$ & Medium & $\mathrm{n}$ & \\
\hline Initial SR (steers/ha) & & 0.53 & & 1.05 & & 1.55 \\
\hline \multicolumn{7}{|l|}{ Year 1 (129 days) } \\
\hline Average SR (steers/ha) & & 0.50 & & 1.05 & & 1.40 \\
\hline $\mathrm{Kg}$ animal/ha at turnout & & 108 & & 216 & & 317 \\
\hline Daily weight gain (g) & 6 & $630 \pm 58^{\mathrm{a} 2}$ & 14 & $341 \pm 97^{b}$ & 18 & $300 \pm 151^{b}$ \\
\hline Live weight gain $(\mathrm{kg})$ per ha & & 40.6 & & 46.2 & & 54.2 \\
\hline \multicolumn{7}{|l|}{ Year 2 (140 days) } \\
\hline Average SR (steers/ha) & & 0.53 & & 1.03 & & 1.32 \\
\hline $\mathrm{Kg}$ animal $/$ ha at turnout & & 129 & & 259 & & 379 \\
\hline \multicolumn{7}{|l|}{ Daily weight gain $(\mathrm{g})$ : } \\
\hline before treatment ( 77 days) & 7 & $865 \pm 151^{\mathrm{a}}$ & 13 & $466 \pm 233^{b}$ & 21 & $382 \pm 207^{b}$ \\
\hline after treatment (63 days) & 7 & $200 \pm 146^{a}$ & 13 & $223 \pm 145^{a}$ & 14 & $86 \pm 158^{a}$ \\
\hline Live weight gain $(\mathrm{kg})$ per ha & & 38.7 & & 47.5 & & 47.3 \\
\hline
\end{tabular}

${ }^{1} \mathrm{n}=$ number of animals.

${ }^{2}$ Different superscript in the same row indicates significant differences by Bonferroni's test $(\mathrm{p}<0.01)$.

common reed (Phragmites australis) and bush grass (Calamagrostis epigeios). The latter which was found in a patchy distribution covering approx. $20-30 \%$ of the area, is a tough grass of low nutritive value and palatability. Apart from grasses, there were some solitary hawthorne (Cratageus monogyna) and thickets of birch (Betula spp.) and willow (Salix spp.). The production of herbage dry matter was estimated to be less than 2 ton/ha/year.

\section{Meteorological observations}

Meteorological data were obtained from the nearby Copenhagen Airport (Table 1). In the first year, April and May were almost without rain and relatively warm and resulted in a water deficit in the area. July, August and September were cold and received rainfall about twice the average. In the second year, July was extremely warm and dry followed by heavy rains in September.

\section{Animals and experimental design}

Each year, forty-two 6-9 month old bull calves (40 Holstein Friesians, 2 Red Dane or cross breds) were selected from a mob of 90 eartagged calves, originating from 18-19 farms. In the first year, average live weight ( \pm s.d.) was $206 \pm 45 \mathrm{~kg}$ and in the second year $245 \pm 38 \mathrm{~kg}$. The animals were raised indoors. All animals tested negative for persistent infection with BVD-virus. After stratification on body weight, calves were randomly allocated to groups of 7 , 14 and 21 animals thus establishing initial SRs of $0.53,1.05$ and 1.55 steers/ha in the 3 paddocks (A-C), respectively (Table 2). Paddock A was placed between paddock $B$ and $C$. In both years, all groups were treated with fenbendazole (Panacur ${ }^{\circledR} ; 7.5 \mathrm{mg} / \mathrm{kg}$ body weight) and turned out on pasture 17 May. Within 3 weeks after turnout, all calves were castrated. The animals were stocked until 18 November in year 1 and until 28 October in year 2. The animals were inspected on a daily basis. Three ha of 
each paddock was kept as a reserve. Feed supplementation in equal amounts per animal was provided to compensate for food shortage at the end of the season. Anthelmintic treatment was given when the owner wanted to intervene in case of clinical disease or unthriftiness.

\section{Sampling and analysis}

Body weights, rectal faecal samples and blood samples were obtained every month. Nematode eggs and coccidia oocysts in faeces were quantified using a modified McMaster method (Henriksen \& Aagaard 1976). Faeces was examined for lungworm larvae during part of the first year and the entire second year (Jørgensen \& Madsen 1982). Monthly faecal larval cultures were set up during the second year (Henriksen \& Korsholm 1983). Herbage infectivity was determined every month in the second year. The paddocks were crossed in a $\mathrm{W}$, and duplicate grass samples were plucked, avoiding faecal pads by $20-30 \mathrm{~cm}$. Single samples were obtained in a similar fashion but close to faecal pads in order to determine the presence of lungworm larvae. The herbage samples were soaked overnight in tap water at room temperature and examined for the presence of infective larvae by agar migration according to the method of Jørgensen (1980) but without addition of bile. Results of duplicate samples were averaged. Serum albumin was measured according to Nisbet et al. (1973), and serum pepsinogen was determined using the procedure described by Ross et al. (1967). Total white and red blood cell counts (WBC, RBC) were performed the first year using a model $\mathrm{S} 560$ Coulter counter (Coulter Electronics, UK) and, differential white blood cell counts were performed on 7 steers per group. The salinity of the drinking water was assessed regularly by means of a Jenway 4200 Conductivity Meter (L.T.D., Essex, UK) at reference temperature $25^{\circ} \mathrm{C}$ and a temperature coefficient of $2.2 \%$. Samples of water were taken $25-40 \mathrm{~cm}$ below the surface, whenever possible.

Tracer calves in the second year

Four bull calves (3 Red Dane, 1 Holstein Friesian; 193-323 kg), raised indoors, were added to each of the 3 groups on 5 October. They were grazed for 3 weeks, and after 3 weeks of housing, they were slaughtered for worm counts, using the procedure described for sheep by Thamsborg et al. (1996). The bronchial tree of the lungs was cut open with scissors and inspected for lungworms. Lungs of 2 tracers per group were rinsed thoroughly in water, and immature stages were recovered after sieving (mesh aperture $212 \mu \mathrm{m}$ ).

\section{Statistical analysis}

Group means of egg and oocyst counts $\left(\log _{10}\right.$ transformed $(x+10)$ ), serum albumin and serum pepsinogen were compared by repeated measures analysis of variance (ANOVA), using the GLM procedure of SAS with SR as the main factor (non-class) and the repeated factor time, and by one-factor ANOVA to determine effect of SR at each sampling occasion (SAS Institute Inc. 1990). Sampling days with zero counts in all groups were omitted. Weight gains were compared by one-factor ANOVA. The 2 years were analysed separately, since an anthelmintic treatment in the second year had a profound effect on most parameters. A level of $p<0.05$ was considered significant.

\section{Results}

\section{Clinical observations and feed availability}

In late June of the first year, several steers had diarrhoea, and 2 steers from the high SR group (C) were hospitalized with severe metabolic acidosis. Following one week of palliative treatment, both steers recovered and were returned to the paddocks. However, within 1-2 weeks, both steers died. At the same time (early July) 


\section{$\rightarrow 0.5-1.1-1.6$ steers/ha}
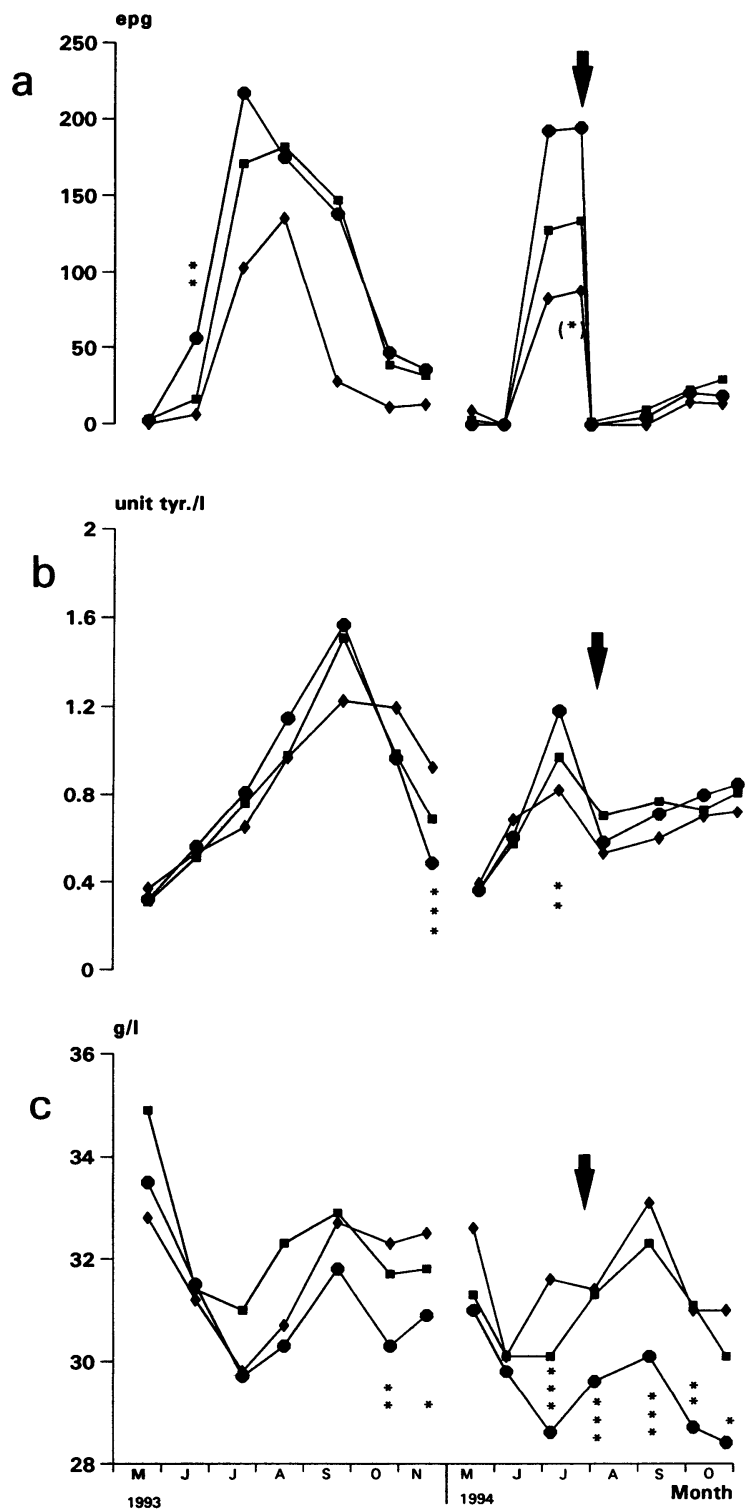

Figure 1. Faecal egg counts (geometric means) (a), levels of serum pepsinogen (b) and levels of serum albumin (c) of steers grazing at different stocking rates during first and second year. Treatment with levamisole is indicated by an arrow. P-values of analysis of variance are indicated by asterisks for each sampling date $\left.\left({ }^{*}\right) \mathrm{p}=0.08 ;{ }^{*} \mathrm{p}<0.05 ;{ }^{* *} \mathrm{p}<0.01 ;{ }^{* * *} \mathrm{p}<0.001\right)$. 
maximum salinity of the drinking water was recorded ranging from $0.13 \%$ in paddock $A$ to $0.37 \%$ in paddock $B$ and $1.22 \%$ in paddock $C$. Immediately the watering point of paddock $\mathrm{C}$ was moved to the same source as paddock A. Two replacement steers were introduced in September. One steer in group A was suffering from chronic, bilateral pneumonia, probably contracted at the farm of origin. It was hospitalized in July and was subsequently omitted from data analysis.

In the second year, diarrhoea was noticed in all groups in late June and July (30\%-55\% incidence) but severe watery diarrhoea was seen in group $\mathrm{C}$ only. Poor weight gains and diarrhoea in combination with low grass availability, primarily in paddock $\mathrm{C}$, prompted the owner to intervene. All groups were treated with levamisole pour-on (Decaris ${ }^{\circledR}$ ) at the recommended dose on 26 July. The SR of group C was subsequently reduced by removing 7 animals on 8 August without affecting the mean live weight of the group. After treatment, a single case of diarrhoea was seen in group C. One steer in group B was excluded in July due to chronic pneumonia.

Due to scarcity of feed in group C, access was allowed to the areas kept as reserve as early as 22 June the first year and 4 July in the second year. In paddock $\mathrm{C}$, and to a lesser extent in paddock B, areas of $F$. rubra and other short grasses were grazed close to ground level in July, and by August an appreciable amount of C. epigeios was consumed. In paddock A, the $C$. epigeios was barely grazed. Later, regrowth of $F$. rubra and other short grasses was observed. This pattern was seen during both years. Supplementary feeding took place from 22 September in the first year and 4 October in the second year (1-1 $1 / 2 \mathrm{~kg}$ concentrate per head per day). From 4 October in the first year, group $\mathrm{C}$ was supplemented with silage ad lib and $2 \mathrm{~kg}$ concentrate.

\section{Parasitological data}

In the first year, individual maximal egg counts rose up to 960,1280 and 2600 epg in the low, medium and high SR groups, respectively, and the effect of SR on faecal egg counts was found to be significant ( $p<0.05$, Fig. 1a). In early July the second year, the effect was marginally significant $(\mathrm{p}=0.08)$ but the infections were terminated by anthelmintic treatment 3 weeks later. After treatment, no significant differences were revealed. A steer in group $\mathrm{C}$ was omitted from data analysis due to heavy infection at turn-out. For most of the 2 nd season, Cooperia (70\%$90 \%$ ) and Ostertagia were predominant in larval cultures. A month after anthelmintic treatment, Ostertagia was more prevalent than Cooperia. Eggs of Nematodirus were seen occasionally.

The coccidia oocyst excretion was highly variable both between and within groups, particularly in early season. No significant differences were found between groups by repeated measures ANOVA. However, 3 weeks after turnout in the second year group $\mathrm{C}$ had significantly higher oocyst counts than the other groups (geometric means of 3,73 and 1480 oocysts per $g$ of faeces in group A,B and C, respectively). During this period group $C$ had a loss in body weight. In the first year, lungworm infection was introduced in the high SR group (C), most likely from a neighbouring field and probably by one of the replacement steers. Within a month, half of the group was found infected (Table 3). No lungworm larvae were detected in faeces from the low and medium SR groups (A and B) but eosinophilia detected in 2-3 of the 7 steers routinely sampled may indicate low grade infections. In accordance, mean total eosinophil counts rose more than five-fold to levels of 0.8$1.010^{9} / 1$ at end of season but they were not related to SR. Analysis of variance of WBCs and $\mathrm{RBCs}$ revealed no major differences between the groups. 
Table 3. Proportion of steers in the low, medium and high stocking rate groups $(0.5,1.1$ and 1.6 steers/ha, respectively) with larvae of $D$. viviparus in faeces or with increased level of blood eosinophils (above $7.5 \%$ ).

\begin{tabular}{|c|c|c|c|c|c|c|c|c|c|}
\hline & \multicolumn{6}{|c|}{ Faecal excretion of D. viviparus } & \multicolumn{3}{|c|}{ Eosinophilia } \\
\hline & \multicolumn{6}{|c|}{ Stocking rate } & \multicolumn{3}{|c|}{ Stocking rate } \\
\hline & \multicolumn{2}{|c|}{ Low } & \multicolumn{2}{|c|}{ Medium } & \multicolumn{2}{|c|}{ High } & \multirow{2}{*}{$\frac{\text { Low }}{+/ n}$} & \multirow{2}{*}{$\frac{\text { Medium }}{t / \mathrm{n}}$} & \multirow{2}{*}{$\frac{\text { High }}{+/ \mathrm{n}}$} \\
\hline & $+/ \mathbf{n}^{1}$ & avg. ${ }^{2}$ & $+/ \mathrm{n}$ & avg. & $+/ \mathbf{n}$ & avg. & & & \\
\hline \multicolumn{10}{|l|}{ Year 1: } \\
\hline 18 Aug & - & - & - & - & - & - & $1 / 7$ & $0 / 7$ & $1 / 7$ \\
\hline $22 \mathrm{Sep}$ & $0 / 6$ & - & $0 / 14$ & - & $1 / 19$ & 498 & $1 / 7$ & $3 / 7$ & $2 / 7$ \\
\hline 25 Oct & $0 / 6$ & - & $0 / 14$ & - & $12 / 21$ & 25 & & $2 / 7$ & $3 / 76 / 7$ \\
\hline $18 \mathrm{Nov}$ & $0 / 6$ & - & $0 / 14$ & - & $9 / 19$ & 15 & & $3 / 7$ & $1 / 76 / 7$ \\
\hline \multicolumn{10}{|l|}{ Year 2: } \\
\hline 5 Sep & $0 / 7$ & & $1 / 14$ & 2 & $0 / 14$ & & - & - & - \\
\hline 4 Oct & $0 / 7$ & & $3 / 12$ & 4 & $3 / 14$ & 1 & - & - & - \\
\hline 28 Oct & $2 / 7$ & 2 & $5 / 13$ & 5 & $1 / 14$ & 4 & - & - & - \\
\hline
\end{tabular}

$1+/ \mathrm{n}=$ positive animals/no. examined.

$2 \mathrm{avg} .=$ average excretion of larvae per $10 \mathrm{~g}$ of faeces amongst infected animals.

Lungworm infection at low levels was observed in all groups in the second year.

\section{Pasture larval counts in 2nd year}

Levels of infectivity of gastro-intestinal nematodes between 17 and $819 \mathrm{~L} 3 / \mathrm{kg}$ dry herbage were observed at turn-out and early June. In the dry month of July and in early August, larval recovery was practically nil but rose dramatically in September, coinciding with rains, and reached maxima of 18000,55000 and 46000 $\mathrm{L} 3 / \mathrm{kg}$ on paddocks $\mathrm{A}, \mathrm{B}$, and $\mathrm{C}$, respectively, on 3 October. In late October, levels were 478, 1385 and $2182 \mathrm{~L} 3 / \mathrm{kg}$ on paddock A, B, and C, respectively. Ostertagia and Cooperia constituted the majority of larvae. On paddock B and C, $10 \%-20 \%$ of the larvae were Nematodirus. A similar pattern was observed with herbage samples taken close to faecal pads, but maximum levels were much higher: 37000,264000 and $212000 \mathrm{~L} 3 / \mathrm{kg}$ on paddocks $\mathrm{A}, \mathrm{B}$, and $\mathrm{C}$, respectively.

\section{Serum pepsinogen and serum albumin}

During the first grazing season, serum pepsinogen levels rose constantly until late September when supplementation was initiated (Fig. 1b). In group A, B and C, 50\%, 57\% and 55\% of the steers, respectively, had values $\geq 1.5$ unit/l, with individual values up to 2.9 units/l. The second year, a significant effect of SR was observed in early July $(\mathrm{p}<0.01)$, and $0 \%, 15 \%$ and $39 \%$ in group A, B and C, respectively, had values $\geq 1.5$ unit/l. The increase was abrogated due to anthelmintic treatment in late July, a week prior to sampling, and even though pasture infectivity by herbage sampling was considerable in October, no further increase was seen. Over the whole season, the effect of SR was not significant $(\mathrm{p}=0.13)$. In both years, serum albumin levels decreased drastically following turn-out and increased during August and September (Fig. 1c). Despite supplementary feeding in October, serum albumin levels continued to decrease. The overall effect of SR was marginally significant the first year $(\mathrm{p}=0.07)$ and signifi- 


\section{$0.5-1.1-1.6$ steers/ha}

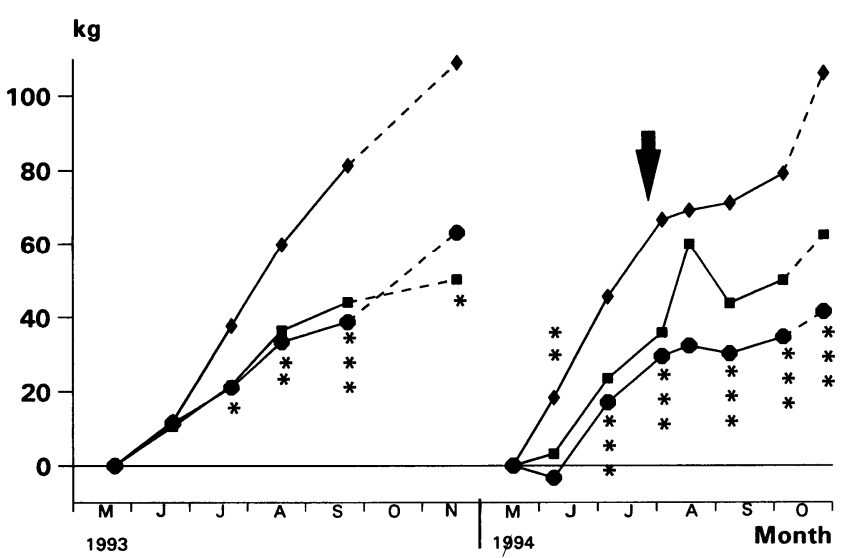

Figure 2. Mean accumulated live weight gains of steers grazing at different stocking rates during first and second year. Gains during periods of supplementation are indicated with dashed lines and treatment with levamisole is shown by an arrow. P-values of analysis of variance are indicated by asterisks for each sampling date $\left({ }^{*} \mathrm{p}<0.05 ;{ }^{* *} \mathrm{p}<0.01 ;{ }^{* * *} \mathrm{p}<0.001\right)$.

cant the second year both before and after treatment $(\mathrm{p}<0.05)$.

\section{Weight gains}

The effect of SR on live weight gains before supplementation was significant the first year $(p<0.001)$ and significant the second year, both before and after anthelmintic treatment $(p<0.0001)$ (Fig. 2). In both years, the analysis showed a significant effect of SR within one or 2 months after turn-out $(p<0.05)$. In the second year, the growth rates in all groups were markedly reduced from early August onwards. A transitory increase in group B in August followed 1-2 weeks after anthelmintic treatment but was otherwise difficult to relate to management changes or food on offer. A higher net production, in terms of $\mathrm{kg}$ of live weight gain/ha, with increasing SR, was observed in the first year. However, in the second year, the high SR group failed to produce more than the medium SR group, primarily due to withdrawal of 7 animals (Table 2).

\section{Tracer calves}

One tracer calf in group A was removed from pasture after 2 weeks and treated for indigestion and pneumonia. The worm count of this particular tracer 4 weeks later was approx. 5\% (total of 1080) of the mean counts of the other tracers in the group (Table 4). In all 3 groups, $82 \%$ $99 \%$ of the Ostertagia spp. were arrested stages recovered by digestion of the abomasal mucosa. Apart from $N$. helvetianus, $69 \%-100 \%$ of the nematodes in the small intestine were immature stages, most likely L4 of Cooperia spp. No significant differences were found between groups. A few immature stages of lungworm were found in the bronchial tree in calves of all groups. Faecal egg excretion from 4-5 weeks after turn-out was predominantly Cooperia (87\%). Tracers on paddock A gained $9 \mathrm{~kg}$ on 
Table 4. Worm counts (arithmetic means \pm s.d.) of tracer calves turned out 5 October for 3 weeks in year 2.

\begin{tabular}{lccc}
\hline & \multicolumn{3}{c}{ Paddock } \\
\cline { 2 - 4 } $\begin{array}{l}\text { Number of nematodes } \\
\text { recovered in: }\end{array}$ & $\begin{array}{c}\text { Low SR } \\
(\mathrm{n}=3)\end{array}$ & $\begin{array}{c}\text { Medium SR } \\
(\mathrm{n}=4)\end{array}$ & $\begin{array}{c}\text { High SR } \\
(\mathrm{n}=4)\end{array}$ \\
\hline $\begin{array}{l}\text { Abomasum: } \\
\text { Ostertagia } \text { spp. }\end{array}$ & $313 \pm 212$ & $404 \pm 159$ & $285 \pm 181$ \\
Inhibited larvae & $16033 \pm 7460$ & $14762 \pm 7986$ & $12200 \pm 5616$ \\
& & & $285 \pm 427$ \\
Small intestine: & $2124 \pm 2843$ & $403 \pm 425$ & $755 \pm 968$ \\
Cooperia oncophora & $633 \pm 252$ & $1207 \pm 1580$ & $3690 \pm 2557$ \\
Immatodirus helvetianus & $5849 \pm 5511$ & $5950 \pm 3888$ & $17215 \pm 5063$ \\
Total & $24953 \pm 15439$ & $22725 \pm 10370$ & \\
\hline
\end{tabular}

average whereas tracers on paddock $\mathrm{B}$ and $\mathrm{C}$ lost 6 and $11 \mathrm{~kg}$, respectively, during the period of grazing. They were offered $1-1 \frac{1}{2} \mathrm{~kg}$ of supplementary feed (concentrate) per day.

\section{Discussion}

In this study of internal parasitism in extensively grazed dairy breed steers, we found a positive correlation between stocking rate (SR) and faecal egg counts in the first year and part of the second year. Although the correlation between worm numbers and faecal egg counts may sometimes be questionable in Ostertagia infections (Kloosterman et al. 1991), it was also evident that all groups acquired substantial worm burdens, despite generally low SRs. This is consistent with serum pepsinogen levels, and with the observation of Bryan \& Kerr (1988) that even at low SRs some parts of pastures are grazed intensely, which may thus facilitate acquisition of infection. Furthermore, the productivity of the pastures was low, and the grazing pressure, defined as number of animals per unit available forage (Anon. 1992), was obviously high. This may result in a low plane of nutrition and hence possibly adverse effects on immunity.

The presently observed association between faecal egg counts and SRs is confounded by possible reduced faecal output at higher SRs when forage is limited, but this would not account solely for the observed differences. It is not possible to conclude to what extent the effect of SR is due to high animal density per se or to reduced nutritional status and thus lowered resistance affecting worm burdens. There was evidence in the second year that the uptake of Ostertagia larvae, as indicated by a rise in serum pepsinogen, was also positively correlated with SR. Yet, unfortunately the course over the season could not be followed due to anthelmintic treatment on 26 July for reasons previously explained. It has earlier been noticed that serum pepsinogen may decline markedly as early as 2-3 days after treatment (Hilderson et al. 1991). Our data has confirmed earlier observations in dairy breed heifers on improved pastures i.e. sown and fertilized pastures (Hansen et al. 1981, Hansen 1982, Nansen et al. 1988). In beef cattle, Ciordia et al. (1971) demonstrated an association between worm burdens and SR. Donald et al. (1979) found, also studying beef cattle, after 3 seasons a positive correlation between worm burdens and SRs but failed to see it the first 2 years at lower infection levels. Similarly, Hansen et al. (1989) did not find any association in a study where infection levels were low. 
The seasonal pattern of egg excretion, characterized by a peak in July and followed by a rapid decrease, differ from the bimodal pattern most often seen in dairy heifer calves which has a primary peak after uptake of overwintered infection, and subsequently a secondary peak due to uptake of the new generation of infective larvae in July/August (Foldager et al. 1981). Explanations for low egg counts in late season could be the high propensity for inhibition of Ostertagia (and Cooperia), development of immunity or a low intake of infective larvae in late season either due to supplementary feeding or scarcity of herbage. The relative importance of the latter factors is unknown. The early and rapid increase in serum pepsinogen in the second year may reflect a high overwintering infection of Ostertagia. This could be related to the late increase in herbage infectivity in the previous year, cf. observations by Nansen et al. (1989). The increase in both pepsinogen and faecal egg counts in the early season was contrasted by the low number of infective larvae recovered from the herbage samples during the same period. This may be due to the animals selective grazing in the early season that cannot be mimicked by the W-traversing random picking up of herbage by hand under extensive conditions.

The high level of inhibition of Ostertagia spp. in tracer calves in October is in accordance with earlier findings in Denmark (Satrija \& Nansen 1992). A possible inhibition of Cooperia spp. as well, has been indicated by Christensen (1991). The relationship between SR and worm burdens of tracer calves in October was not easy to conclude upon. It contrasted the marked differences found in larval numbers by herbage analysis. It is likely that the feed intake of tracers was inversely related to SR and thus, level of worm burdens did not reflect the infectivity of the respective paddocks, as intended. This was possibly confirmed by the highly variable but yet considerable overall weight loss of tracers in paddocks $\mathrm{B}$ and $\mathrm{C}$ compared to paddock $\mathrm{A}$, indicating large differences in the amount of herbage consumed. The change of environment from stall-fed conditions to turn-out onto pasture with scarce and poor quality grazing and adverse weather might obviously have been too harsh. The grazing of tracer calves may have been affected by the social adjustments necessary in different sized groups. The worm burden of the single animal withdrawn from paddock A due to disease indicated a very limited intake of infected herbage in the first 2 out of 3 weeks. The results indicate that under extensive grazing conditions, where larger parts of the paddocks are left ungrazed, reliable estimation of pasture infectivity may be confronted with difficulties. A similar availability of herbage between paddocks is imperative if tracer calves are to be used.

In both years, the animal production $(\mathrm{kg}$ gain per ha) was increasing or roughly similar at higher SRs. However, under the reported conditions, and taking into account the rapidly decreasing average weight gains with increasing $\mathrm{SR}$, and thus prolonged production times, a SR closer to low than medium seems to be advisable. The precise effects of nematodes on productivity cannot be assessed directly by the current design. In both years, serum pepsinogen levels above 1.5 units tyrosine/ 1 in a considerable proportion of the animals indicated levels of gastrointestinal nematode infection that are usually associated with production losses in dairy heifers (Foldager et al. 1981). Bull calves are usually regarded as more susceptible to worms than heifers whereas steers are in between or similar to heifers in susceptibility (Herd et al. 1992). Most of the present bull calves/steers would have been raised at a high plane of nutrition before turnout. The decline in growth rate at the high SR following turnout the second year, indicated limited availability and 
uptake of nutritive grasses and possibly difficulties for the dairy breed steers to adjust to the grazing situation. It is not likely that nematode infections affected the steers at this stage. A possible impact of coccidiosis cannot be ruled out, as indicated by oocyst counts. In August, the anthelmintic treatment reduced the incidence of diarrhoea but failed to prevent low growth rates. This shows that feed on offer and perhaps other nutritional factors, rather than nematode infections, was the main limiting factor in late season. Supplementary feed or marked reduction in stocking rate is probably necessary in late season to match the decreasing availability and nutritive value of the pasture. The relative influence of herbage protein content and protein losses due to nematode infections cannot be estimated from the present investigation. Field outbreaks of dictyocaulosis may be associated with high SRs (Jørgensen \& Ogbourne 1985). In the first year of the present study, the spread of dictyocaulosis in the high SR group took place after the infection was introduced, possibly from a neighbouring field. In the second year, when patent infections were found in all groups, the incidence of lungworm infections could not be statistically related to SR.

It is most likely that the animals suffering from diarrhoea in the first year was related to intake of salty or brackish water (paddock C). This may not be the sole reason, as levels of salt ranging from $0.1 \%-1.0 \%$ have been encountered without any health problems in cattle ( $R a$ dostits et al. 1994), and $0.5 \%$ seems well tolerated. Salinities of $0.25 \%$ may result in reduced milk production and an increased intake of water after a 4 week period (Jaster et al. 1978). However, mixing calves from different farms may well result in cases of infectious diarrhoea, and intake of brackish water may lead to an exacerbation of the diarrhoea.

We conclude that, under the given range conditions with low grass availability, nematode in- fections constituted a problem and that the level of exposure and uptake of gastrointestinal nematodes in steers was affected by stocking rate, also within these animal densities that were much lower than commonly found on improved pastures. It is likely, but not proven, that control of gastrointestinal nematode infections will improve productivity at higher stocking rates.

\section{Acknowledgements}

The skilful assistance of A. Pedersen, M. Pearmann and N. Midtgård and support from "Johan og Hanne Weimann" foundation, Odense and the Danish National Research Foundation are greatly appreciated. We are grateful for valuable comments from Dr. Lani Stephenson.

\section{References}

Anonymous: Terminology for grazing lands and grazing animals. J. Prod. Agric. 1992, 5, 191201.

Bryan RP, Kerr JD: The grazing behaviour of cattle in relation to the sampling of infective nematode larvae on pasture. Vet. Parasitol. 1988, 30, 73-82.

Ciordia H, Neville WE, Baird DM, McCampbell HC: Internal parasitism of beef cattle on winter pastures: levels of parasitism as affected by stocking rates. Am. J. Vet. Res. 1971, 32, 1353-1358.

Christensen, CM: Studies of the immune response in cattle infected with normal or inhibited larvae of Ostertagia ostertagi (Trichostrongylidae). Ph.D. thesis, 1991, Royal Vet. and Agric. University, Copenhagen, Denmark.

Donald AD, Axelsen A, Morley FHW, Waller PJ, Donnelly JR: Growth of cattle on phalaris and lucerne pastures II. Helminth parasite populations and effects of anthelmintic treatment. Vet. Parasitol. 1979, 5, 205-222.

Foldager J, Sejrsen K, Brolund Larsen J, Nansen P, Jørgensen RJ, Hansen JW: Control of infection with gastrointestinal helminths in calves and heifers on pasture. 514. Beretning fra Statens Husdyrbrugsforsøg, Frederiksberg, 1981, 325 pp.

Hansen JW: The influence of stocking rate on uptake of trichostrongyle larvae, Ph.D. thesis, 1982, Royal Vet. and Agric. University, Copenhagen, Denmark. 
Hansen JW, Nansen P, Foldager J: The importance of stocking rate on the uptake of gastrointestinal nematodes by grazing calves. In: P Nansen, RJ Jørgensen and EJL Soulsby (Eds.): The epidemiology and control of nematodiasis in cattle. Proc. of the CEC workshop, Copenhagen, 1981. Martinus Nijhoff, The Hague, pp. 471-494.

Hansen JW, Zajac AM, Eversole DE, Gerken Jr. HJ: The effect of stocking rate and parasites control on the performance of replacement beef heifers on pasture. Vet. Parasitol. 1989, 34, 103-115.

Henriksen SA, Aagaard $K$ : A simple flotation and McMaster method, Nord. Veterinærmed. 1976, 28, 392-397.

Henriksen $S A$, Korsholm H: A method for culture and recovery of gastrointestinal strongyle larvae. Nord. Vet. Med. 1983, 35, 429-430.

Herd RP, Queen WG, Majewski GA: Sex-related susceptibility of bulls to gastrointestinal parasites. Vet. Parasitol. 1992, 44, 119-125.

Hilderson H, Dorny P, Berghen P, Vercruysse J, Fransen J, Braem L: Gastrin and pepsinogen changes during an Ostertagia ostertagi challenge infection in calves. J. Vet. Med. B 1991, 38, 25-32.

Jaster EH, Schuh JD, Wegner TN: Physiological effects of saline drinking water on high producing dairy cows. Journal of Dairy Science, 1978, 61, 66-71.

Jørgensen RJ: The epidemiology of bovine dictyocaulosis in Denmark. Vet. Parasitol. 1980 7, 153167.

Jørgensen RJ, Madsen $K$ : [Examination of bovine faeces for the presence of $D$. viviparus larvae]. Dansk Veterinær Tidsskrift. 1982, 65, 517-518.

Jørgensen RJ, Ogbourne CP: Bovine dictyocauliasis: a review and annotated bibliography. Misc. publ. No. 8, 1985, Commonwealth Agricultural Bureau, UK, $104 \mathrm{pp}$.

Kloosterman A, Ploeger HW, Frankena K: Age resistance in calves to Ostertagia ostertagi and Cooperia oncophora. Vet. Parasitol. 1991, 39, 101113.

Nansen P, Foldager J, Hansen JW, Henriksen SA, Jørgensen RJ: Grazing pressure and acquisition of O. ostertagi in calves. Vet. Parasitol. 1988, 27, 325-335.

Nansen PJ, Grønvold J, Jørgensen RJ, Henriksen SA, Foldager J, Sejrsen K: Outbreaks of early- season trichostrongylosis in calves in Denmark. Vet. Parasitol, 1989, 32, 199-211.

Nisbeth J, Jarvis A, Fenton A: Measurement of human serum albumin with bromcresole green. A simultaneous comparison of two methods on the SMA 12/60. Clin. Chim. Acta, 1973, 45:189191.

Radostits OM, Blood DC, Gay CC: Veterinary Medicine, 8 ed., 1994, Bailliérie Tindall, London.

Ross JG, Purcell DA, Dow C, Todd JR: Experimental infection of calves with Trichostrongylus axei. The course of development of infection and 1esions in low level infections. Res. Vet. Sci. 1967, 8, 201-206.

SAS Institute Inc.: SAS Users guide: Statistics, version 5, Cary, NC, USA 1990.

Satrija F, Nansen P: Acquisition of inhibited early fourth stage Ostertagia ostertagi larvae in tracer calves in late summer and early autumn. Bull. Scand. Soc. Parasitol. 1992, 2, 20-22

Thamsborg SM, Jørgensen RJ, Waller PJ, Nansen P: The influence of stocking rate on gastrointestinal nematode infections of sheep over a two-year grazing period. Vet. Parasitol. 1996, 67, 207-224.

\section{Sammendrag}

Endoparasitcere infektioner hos stude ved ekstensiv afgroesning.

Betydningen af belægningsgrad på infektioner med indvoldsorm blev undersøgt hos stude under ekstensiv afgræsning. To hold af 42 førstegangsgræssende SDM stude blev fulgt i 2 sæsoner fra maj-oktober på et $\mathbf{4 0}$ ha inddæmmet, ugødsket naturareal. Studene blev i begge sæsoner opdelt i 3 grupper, der afgræssede separate folde ved henholdsvis lav, middel og høj belægningsgrad (0,53, 1,05 og 1,55 stude/ha). Ægudskillelsen, der hovedsagelig bestod af Cooperia og Ostertagia æg, var det første år og i en del af anden sæson afhængig af belægningsgraden $(\mathrm{p}<0,05$; $\mathrm{p}=0,08$ ). Det første år fandtes maksimale geometriske gennemsnit på 135, 182 og 217 epg ved henholdsvis lav, middel og høj belægningsgrad, og i anden sæson gennemsnit på 88,134 og 195 epg. I det andet år blev alle stude behandlet med levamisol 26 juli på grund af diarre og ringe tilvækst, der især var markant ved høj belægningsgrad, hvorfor 7 stude måtte fjernes fra denne gruppe. Serumpepsinogenniveauet blandt studene $\mathrm{i}$ anden sæson før ormebehandling tydede på en større optagelse af infektive larver af Ostertagia ved højere belægning $(\mathrm{p}<0.01)$. Den gennemsnitlige tilvækst det første år var $630 \pm 58,341 \pm 97$ og $300 \pm 151 \mathrm{~g} / \mathrm{dag}$ ved henholdsvis lav, middel og høj belægningsgrad, og i den anden sæson var de tilsvarende tal $565 \pm 109,357 \pm 135$ og 
$247 \pm 129 \mathrm{~g} /$ dag. Ved ekstensiv afgræsning med stude blev det konkluderet, at græssmitten og studenes optagelse af indvoldsorm var afhængig af belægningsgraden. Sidst på sæsonen var den tilgængelige foder- mængde den begrænsende faktor for dyrenes tilvækst, men ved middel og høj belægningsgrad var det sandsynligt, at også infektion med indvoldsorm påvirkede studenes produktion.

(Received October 13, 1997; accepted March 19, 1998).

Reprints may be obtained from: S. M. Thamsborg, Organic Livestock Production, Department of Animal Science and Animal Health, The Royal Veterinary and Agricultural University, Grønnegårdsvej 2, DK-1870 Frederiksberg C, Denmark. E-mail: smt@kvl.dk, tel.: +45 3528 3028, fax: +45 35283055. 
